CASSOWARY Volume I (2): 95 - 104

ISSN : 2614-8900

E-ISSN : 2622-6545

CProgram Pascasarjana Universitas Papua, https://pasca.unipa.ac.id/

\title{
Kajian sistem pengelolaan lingkungan stasiun pengisian bahan bakar umum di Manokwari
}

\section{Review of environmental management system of public station petrolium at Manokwari}

Christmas Yulian Sonya Marola, Nurhaidah I. Sinaga, B.M.G. Sadsoetoeboen

Program Studi Ilmu Lingkungan, Universitas Papua

Jalan Gunung Salju Amban, Manokwari, Papua Barat, Indonesia

*Email:

\begin{abstract}
This research was designed to describe the environmental management system employed by public station petroleum at Manokwari, using variables of their implementation to public petroleum station regulations, environmental policies, structural and official/personal organization, environmental protection facilities, procedures, and water waste management. The results show that implementations for public petroleum station regulation, SPBU 84.983.01 and 84.983.02 are relatively good, or good management, but SPBU 81.983.05 is fairly good or environmental management is good enough. SPBU 84.983.01 and SPBU 81.983.05 have good enough for structural or personal organization, and SPBU 84.983.02 is good for its structural and personal organization. Others aspects of physical and environmental protection facilities SPBU 84.983.02 is good, while SPBU 84.983.01 is fairly good. Another public station petroleum of SPBU 81.983.05 is not fulfillment the physical and environmental protection facilities or under good criteria. Water quality usages for monitoring tanks of all public stations petroleum are fulfilled the standard. However, the water quality released from the public station petroleum to drainages, rivers, or sea are not fulfilled the water and sanitation standards.
\end{abstract}

Keywords: Environmental management system, public station petroleum, water waste quality, andquality standard.

ABSTRAK: Penelitian yang dilakukan bertujuan mendiskripsikan sistem pengelolaan lingkungan yang diimplementasikan oleh SPBU di Manokwari melalui penilaian tingkat kepatuhan terhadap peraturan dan kebijakan lingkungan, kelengkapan organisasi dan personil, kondisi fisik sarana lindungan lingkungan dan kualitas air limbah yang di hasilkan. Hasil penelitian menunjukkan bahwa tingkat kepatuhan terhadap peraturan SPBU 84.983.01 dan 84.983.02 tergolong kriteria taat atau mutu pengelolaan baik, sedangkan SPBU81.983.05 tergolong cukup taat atau pengelolaan lingkungan cukup baik. Berdasarkan aspek kelengkapan organisasi dan personil,SPBU 84.983.01 dan SPBU 81.983.05 tergolong kriteria cukup taat atau kelengkapan organisasi dan personil cukup baik, sedangkan SPBU 84.983.02 tergolong kriteria taat kelengkapan oranisasi dan personil baik.Ditinjau pada aspek kondisi fisik sarana lindungan lingkungan, SPBU 84.983.02 tergolong kriteria taat atau kondisi fisik sarana lingkungannya baik.SPBU 
84.983.01 tergolong kriteria cukup taat atau kondisi fisik sarana lingkungannya cukup baik.Sedangkan SPBU 81.983.05 tergolong kurang taat atau kondisi fisik sarana lingkungannya kurang baik. Kualitas air limbah yang bersumber dari bak pemantau ke tiga SPBU memenuhi baku mutu yang disyaratkan, sedangkan kualitas air limbah dari saluran drainase, sungai dan laut tidak memenuhi syarat baku mutu yang ditetapkan.

Kata Kunci: Kajian Sistem pengelolaan lingkungan, Stasiun pengisian bahan bakar umum, kualitas air limbah, dan baku mutu

\section{PENDAHULUAN}

Masalah lingkungan hidup tidak hanya mencakup masalah pencemaran dan kerusakan lingkungan semata, melainkan telah menjadi bagian integral dari masalah pembangunan secara keseluruhan. Karena itu masalah lingkungan menjadi tanggung jawab lintas sektoral dan multidisipliner serta melibatkan kepentingan seluruh masyarakat (Courtier,1995). Pelaksana setiap usaha pembangunan wajib mengupayakan penanganan dampak yang mungkin ditimbulkan dengan memini-mumkan dampak negatif dan memak-simumkan dampak positif. Upaya-upaya meminimalkan dampak negatif dan memaksimalkan dampak positif dari setiap kegiatan pembangunan harus didasarkan pada prinsip rasionalisasi terhadap pilihan teknologi yang digunakan sehingga berlangsung efektif dan efisien. Wiku (2008) menyatakan bahwa technology end of pipe dalam penanganan dampak di negara-negara maju telah ditinggalkan karena di nilai dapat menambah menambah biaya produksi dan tidak mendorong upaya untuk perbaikan kualitas lingkungan hidup secara dini.

Sistem Pengelolaan lingkungan olehSPBU mengacu dan berpedoman pada Undang - Undang No. 32 Tahun 2009 tentang Perlindungan dan Pengelolaan Lingkungan hidup, Undang Undang No.1 Tahun 1970 tentang Keselamatan.

Kerja, Dokumen UKL-UPL SPBU, Pedoman LLK3 PT. Pertamina
Bidang Pemasaran dan Niaga (PT. Pertamina 2004a). Penaatan akan pedoman dan peraturan tersebut di atas merupakan bentuk tanggung jawab dan kepedulian pihak manajemen SPBU terhadap pengelolaan lingkungan hidup kepada pemerintah. Karena itu PT. Pertamina sebagai induk perusahaan dari SPBU mengeluarkan Standar Operasional Prosedure (SOP) dalam menjalankan usaha SPBU di seluruh Indonesia (PT. Pertamina, 2004b).

SPBU (Stasiun Pengisian Bahan

Bakar Umum) merupakan prasarana umum yang di sediakan oleh PT. Pertamina (Persero) untuk melayani masyarakat luas dalam pemenuhan kebutuhan bahan bakar minyak. SPBU sebagai penyalur resmi Bahan Bakar Minyak (BBM) maka dalam proses pembangunan dan operasionalisasinya harus memenuhi standar yang ditetapkan oleh PT. Pertamina. SPBU di kota Manokwari, terdiri atas SPBU 84.983.01 Sanggeng, SPBU 81.983.05 Wosi, dan SPBU 84.983.02 Esau Sesa merupakan penyalur utama bahan ba-kar minyak jenis premium, solar dan pertamax. Kehadiran SPBU di kota ini diharapkan bisa melayani konsumen dengan maksimal dalam menunjang pergerakan ekonomi. SPBU harus memberikan pelayanan yang prima dengan fasilitas penunjang yang memadai sesuai standar PT. Pertamina (Persero). Observasi pendahuluan menunjukkan bahwa ketersediaan sarana lindungan lingkungan seperti taman indikator, tempat sampah 
dan kondisi yang bersih belum memadai se-bagaimana yang disyaratkan. Fakta tersebut menimbul-kan pertanyaan apakah SPBU telah menerapkan sistem pengelolaan lingkungan dalam menjalankan usahanya. Pertanyaan tersebut merupakan masalah yang akan di jawab melalui penelitian ini.

Penelitian bertujuan untuk mendiskripsikan implementasi sistem pengelolaan lingkungan SPBU di Manokwari melalui Tingkat kepatuhan manajemen SPBU terhadap peraturan dan kebijakan lingkungan, kelengkapan organisasi dan personil serta kondisi fisik sarana lindungan lingkungan yang disyaratkan.

\section{METODE PENELITIAN}

\section{Waktu dan Tempat Penelitian}

Lokasi Penelitian dilakukan di tiga (3) SPBU di Kota Manokwari yaitu; SPBU 84.983.01 Sanggeng, SPBU 81.983.05 Wosi dan SPBU 84.983.02 Jalan Baru Esau Sesa Manokwari. Waktu pelaksanaan pengumpulan data lapangan dilakukan mulai bulan Oktober 2014 sampai dengan bulan Juli 2015.

\section{Alat dan Bahan Penelitian}

Alat yang digunakan dalam penelitian ini adalah kuisioner, dan alat dokumentasi berupa Kamera foto dan Video untuk mendoku mentasikan hasil survei,GPS (Global Positioning System) digunakan untuk menentukan posisi titik sampel. Bahan penelitian adalah dokumen perizinan SPBU, dokumen UKL/ UPL, Pedoman LLK3 PT. Pertamina (Persero), SOP Pengelolaan SPBU.

\section{Teknik Pengumpulan Data}

Metode penelitian yang digunakan adalah metode deskriptif dengan teknik review dokumen, wawancara, dan observasi lapangan. Review doku-men dilakukan untuk mengetahui ketersedia- an dan kelengkapan serta keter-arsipan semua dokumen pengelolaan lingkungan yaitu dokumen UKL/UPL masingmasing SPBU, dokumen LLK3, Kebijakan organisasi, ketenagaan dan kelengkapan peralatan K3, sosialisasi, implementasi, pemantauan dan evaluasi. Wawancara dilakukan untuk memperoleh data tentang implementasi program pengelolaan dan pemantauan lingkungan di setiap SPBU. Observasi lapangan dilakukan untuk mengetahui kondisi lingkungan spesifik areal di setiap SPBU sekaligus untuk verifikasi hasil review dokumen pengelolaan lingkungan yang dimiliki.

Responden contoh ditentukan secara purposive merupakan keterwakilan dari pimpinan/manajer, staf manajemen foreman BBM yaitu supervisior, Teknisi/petugas pembongkaran BBM, tangki pendam, Oil Cathcer dan operator pompa dispenser pada masing-masing SPBU adalah 16 orang responden SPBU 84.983.01, 8 orang res-ponden SPBU 81.983.05, dan 19 orang responden. Jenis data yang dikumpulkan terkait dengan pelaksanaan kebijakan/SOP, program pengelolaan lingkungan dan monitoring lingkungan yang dilakukan oleh manajemen SPBU.

Observasi dilakukan pada masing-masing SPBU untuk melihat kesesuaian/kenyataan yang ada dilapangan dengan dokumen UKL/UPL yang disyaratkan dan melihat kesesuaian pelaksanaan/operasionalisasi dilapangan menurut SOP PT. Pertamina (Persero) sebagai bentuk penaatan akan pedoman kerja pihak manajemen terhadap pengelolaan lingkungan sekaligus verifikasi data hasil wawancara.

Variabel yang diamati dalam penelitian ini adalah:

1. Kepatuhan terhadap peraturan perundangan

2. Kelengkapan Organisasi dan Personil 
3. Kesesuaian fisik sarana lindungan lingkungan.

Untuk operasionalisasi variabel menggunakan metode skala Guttman (Sugiyono.2014), yaitu suatu metode kuantifikasi dengan dua alternatif nilai scoring atas indikator jawaban yang diberikan atas pertanyaan yang diajukan. Bila jawaban sesuai dengan jawaban yang diharapkan diberi skor $=1$ dan bila bertentangan diberi skor $=0$.

Tingkat kepatuhan terhadap setiap variabel pengamatan menggunakan persentase yaitu persen kepatuhan yang dihitung berdasarkan rumus sebagai berikut :

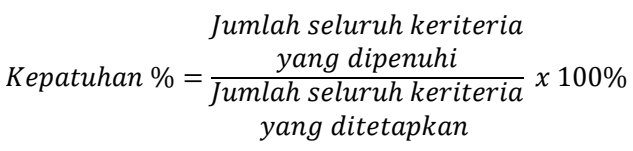

Maka pengambilan kesimpulan dalam penilaian masing-masing variabel kriteria kepatuhan sebagaimana disajikan pada Tabel 1.

Tabel 1. Kriteria tingkat kepatuhan untuk penarikan kesimpulan

\begin{tabular}{|c|c|c|c|}
\hline No. & $\begin{array}{c}\text { Kriteri } \\
\text { Kepatuhan }\end{array}$ & $\begin{array}{c}\text { Kepatuhan } \\
(\%)\end{array}$ & Keterangan \\
\hline 1 & Sangat Taat & $81-100$ & $\begin{array}{l}\text { Pengelolaan SPBU berjalan Sangat Baik } \\
\text { ditinjau dari variabel yang bersangkutan. }\end{array}$ \\
\hline 2 & Taat & $61-80$ & $\begin{array}{l}\text { Pengelolaan SPBU berjalan Baik ditinjau dari } \\
\text { variabel yang bersangkutan. }\end{array}$ \\
\hline 3 & Cukup Taat & $41-60$ & $\begin{array}{l}\text { Pengelolaan SPBU berjalan Cukup Baik } \\
\text { ditinjau dari variabel yang bersangkutan. }\end{array}$ \\
\hline 4 & Kurang Taat & $21-40$ & $\begin{array}{l}\text { Pengelolaan SPBU berjalan Kurang Baik } \\
\text { ditinjau dari variabel yang bersangkutan. }\end{array}$ \\
\hline 5 & Tidak Taat & $0-20$ & $\begin{array}{l}\text { Pengelolaan SPBU tidak berjalan sama sekali } \\
\text { ditinjau dari variabel yang bersangkutan. }\end{array}$ \\
\hline
\end{tabular}

Tabel 2. Rata-rata persentase kepatuhan SPBU di Manokwari terhadap Sistem manajemen lingkungan.

\begin{tabular}{llccc}
\hline & & \multicolumn{3}{c}{ Persen Kepatuhan (\%) } \\
\cline { 3 - 5 } No. & \multirow{2}{*}{ Variabel Pengamatan } & SPBU 1 & SPBU 2 & SPBU 3 \\
& & $\mathbf{8 4 . 9 8 3 . 0 1}$ & $\mathbf{8 1 . 9 8 3 . 0 5}$ & $\mathbf{8 4 . 9 8 3 . 0 2}$ \\
\hline 1. & Kepatuhan terhadap perundangan & 71,65 & 49,16 & 71,65 \\
2. & $\begin{array}{l}\text { Kelengkapan organisasi dan } \\
\text { personalia }\end{array}$ & 59,62 & 53.61 & 66,56
\end{tabular}


3. Kondisi fisik sarana lindungan lingkungan

Rata-rata

Kriteria Mutu pengelolaan
45,50

58,93

\section{Cukup Baik}

jawab pengelolaan dan pemantauan lingkungan SPBU yang dikelolanya.

\section{Kelengkapan manajemen organisasi dan personil}

Persentase kepatuhan berdasarkan men lingkungan lain yang dimiliki di tingkat manager.

Menurut salah satu komponen dalam sistem manajemen lingkungan yang harus diperhatikan adalah kebijakan lingkungan yang dikeluarkan oleh pihak manajemen sebagai komitmen untuk meleksanakan pengelolaan lingkungan oleh organisasinya (Kuhre, et.al. 1996; SOP PT. Pertamina, 2004b).

SPBU di Manokwari ditinjau dari segi kepatuhan terhadap peraturan dan kebijakan tergolong kriteria taat untuk SPBU 84.983.01 dan SPBU 84.983.02. Artinya bahwa mutu pengelolaan SPBUtergolong baik sekalipun dalam operasionalnya belum berpedoman pada LLK3 dan SOP yang disyaratkan serta belum melaksanakan program pengelolaan dan pemantauan lingkungan seperti yang ditetapkan dalam dokumen UKL/UPL. Namun untuk persyaratan lain seperti kelengkapan administrasi dan dokumen perizinan usaha telah dipenuhi oleh ke dua SPBU.SPBU 81.983.05 tergolong kurang taat dan mutu pengelolaan SPBU kurang baik karena SPBU ini selain belum memiliki dokumen UKL /UPL,juga dalam operasionalnya belum mengikuti pedoman LLK3 dan SOP yang ditetapkan oleh PT. Pertamina Persero. Beberapa persyaratan administrasi dan perizinan usaha juga belum dilengkapi. SPBU ini wajib untuk membuat dokumen UKL/UPL sebagai dasar dalam melaksanakan tanggung
24,92

73,57

42,56

70.59 parameter kelengkapan organisasi dan kebijakan pada ketiga SPBU di Manokwari tergolong cukup taat dan mutu pengelolaan berjalan cukup baik. Ketidaklengkapan organisasi SPBU nampak dari Struktur Organisasi dan pembagian tugas/wewenang atau tang-gung jawab secara tertulis yang tidak tersedia, sehingga pelaksanaan dan pertanggungjawaban terhadap pekerjaan masingmasing unit organisasi tidak optimal.

Khusus untuk SPBU 84.983.02 Jalan Barud dijumpai bahwa tenaga training untuk operator dispenser tidak seluruhnya dapat menggunakan alat pemadam kebakaran. Kualifikasi ini mutlak bagi tenaga operator dispenser SPBU. Karena usaha ini memiliki resiko kebakaran yang tinggi sehingga tenaga operator dispenser wajib memiliki keterampilan dalam mengoperasikan alat pemadam kebakaran yang tersedia.

Tenaga pembongkaran BBM pada SPBU 84.983.01 Sanggeng saat melakukan pembongkaran BBM sering tidak menggunakan alat safety standar yang disyaratkan dalam SOP dan LLK3 Pertamina. Kedisiplinan dalam menggunakan alat safety perlu menjadi perhatian manajemen agar kesehatan dan keselamatan kerja operator dapat terjamin.

Tenaga supervisi di SPBU 84.983.01 tidak memiliki sertifikat kualifikasi yang disyaratkan dan belum berpengalaman dalam bidang retail. Karena 
itu pihak manajemen SPBU bersangkutan wajib mengupayakan pelatihan bagi tenaga retail agar memiliki kualifikasi yang disyaratkan. Dengan memiliki keterampilan yang memadai, maka dapat diminimumkan terjadinya tumpahan minyak pada saat retail.

\section{Kondisi fisik sarana lindungan lingkungan}

Sarana fisik utama lindungan lingkungan untuk usaha SPBU terdiri atas intalasi oil cather dan well cathcr. Sarana lindungan lingungan ini mutlak harus dimiliki oleh setiap SPBU. Kondisi fisik sarana ini harus terus dipelihara sehingga tidak terjadi kebocoran atau tidak bersfungsi sebagaimana mestinya. Tangki Pendammerupakan sarana operional utama di setiap SPBU. Setiap SPBU harus mempunyai desain tangki pendam untuk memudahkan petugas operaional pembongkaran mengetahui keberadaan tangki tersebut. Setiap hari petugas melakukan pemeriksaan sistem pipa secara visual atau Gas Tester.
Kepatuhan terhadap persyaratan kondisi fisik sarana lindungan lingkungan, maka SPBU 84.983.01 dan SPBU 81.983.05 tergolong cukup taat. Kedua SPBU ini mutu pengelolaan lingkungan terutama dari segi perawatan tangki pendam cukup baik sehingga tidak ada kebocoran.Kondisi fisik sarana oil cather dan well cather perlu dioptimalkan sehingga ceceran minyak dapat ditampung dan diendapkan se-belum air limbah dibuang ke saluran drainase umum. Khusus untuk SPBU 84.983.002 kepatuhannya tergolong taat ditinjau dari segi kelengkapan dan kondisi fisik sarana lingkungannya. Mutu pengelolaan lingkungan dapat ditingkatkan dengan meningkatkan pemantauan intensif terhadap sarana fisik lindungan lingkungan yang dimiliki. Kondisi fisik sarana lindungan ling-kungan untuk masing-masing SPBU sepert disajikan pada Gambar 1, Gambar 2 dan Gambar 3.

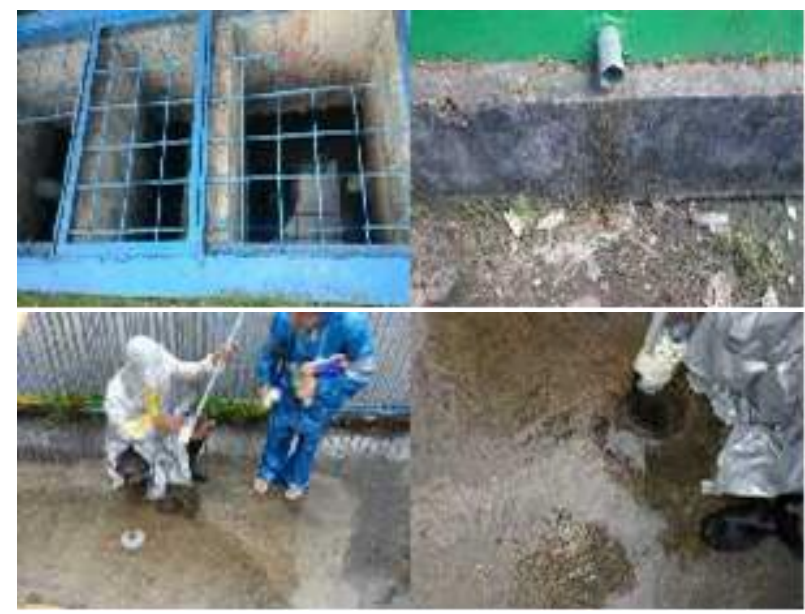

Gambar 1. Sarana Lindungan Lingkungan SPBU 84.983.01 Sanggeng

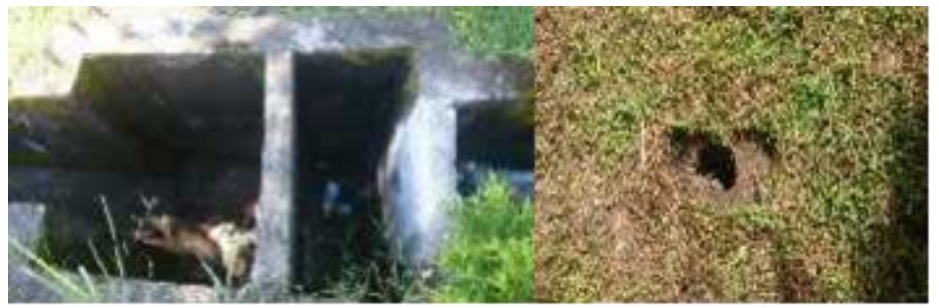




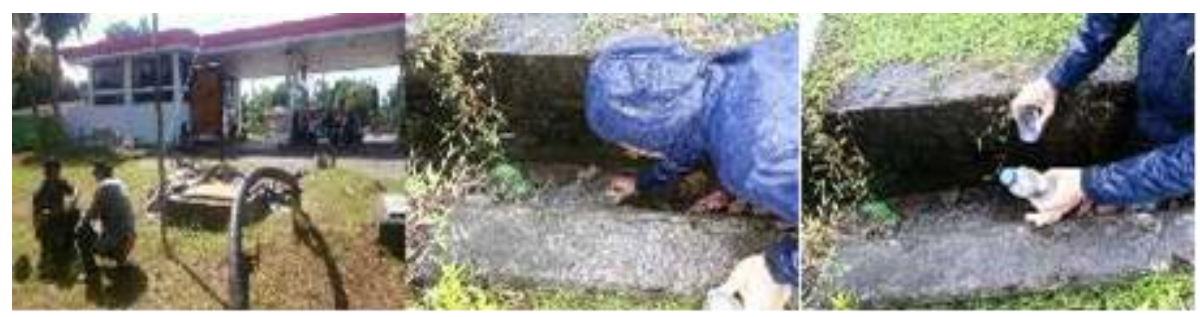

Gambar 2. Sarana Lindungan Lingkungan SPBU 81.983.05 Wosi

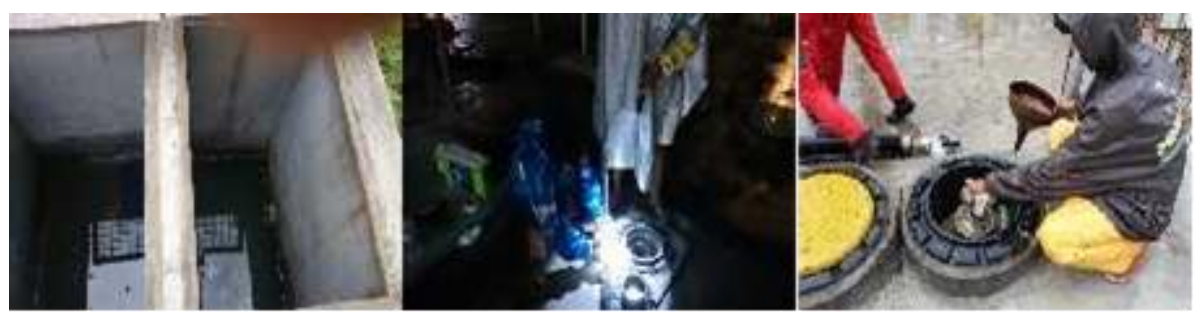

Gambar 2. Sarana Lindungan Lingkungan SPBU 84.983.02 Jalan Baru

Secara umum kepatuhan terhadap ketentuan sistem manajemen lingkungan yang diamati tampak bahwa SPBU 84.983.02 lebih baik dalam mengimplementasikan sistem manajemen lingkungan yang disyaratkan dibanding SPBU 84.983.01 dan SPBU 81.983.05 yang tergolong pada kriteria cukup baik. SPBU 84.983.01 dan SPBU 81.983.03 sekalipun memiliki kriteria agak taat, namun persentase kepatuhannya SPBU 84.983.01 mengimplementasikan sistem manajemen lingkungan dengan mutu lebih baik.

Sekalipun ke tiga SPBU tersebut mengimplementasikan sistem manajemen lingkungan dengan mutu cukup baik sampai baik, namun bila ditinjau dari indikator-indikator penilai serta parameter penilaian tampak bahwa manajemen SPBU di Manokwari belum memiliki sistem manajemen lingkungan baku yang menjadi acuan organisasi untuk melaksanakan pengelolaan lingkungan SPBU yang dikelolanya.

Kebijakan lingkungan, baik kebijakan umum lingkungan maupun kebijakan khusus lingkungansecara internal belum dimiliki oleh setiap SPBU di Manokwari sebagai mana disyaratkan oleh SOP PT. Pertamina (PT. Pertamina, 2015).
Manajemen SPBU di Manokwari belum memiliki komitmen yang kuat untuk mengelola dan melindungi lingkungan hidup disekitar lokasi SPBU. Pihak manajemen lebih mengutamakan kelengkapan peryaratan perizinan usaha dan sarana-prasarana operasional usaha. Sedangkan sarana dan prasarana pendukung LLK3 termasuk instalasi fisik sarana lindungan lingkungan belum menjadi perhatian pihak manajemen. Pedoman LLK3 menjadi salah satu persyaratan mutlak yang harus diimplementasikan oleh manajemen SPBU sebagaimana yang ditetapkan oleh PT. Pertamina sebagai penanggung jawab operasionalisasi SPBU.

Operasionalisasi usaha ketiga SPBU di Manokwari belum menggunakan pedoman LLK3 dan SOP SPBU yang ditetapkan oleh PT Pertamina. Demikian halnya Dokumen UKL/UPL sebagai dokumen perencanaan lingkungan sebagai salah satu syarat perizinan usaha dan juga menjadi alat dalam sistem manajemen lingkungan sekalipun telah disusun oleh pihak SPBU (SPBU 84.983.01 dan SPBU 84.983.02) namun program pengelolaan dan pemantauan lingkungan tidak dilaksanakan. SPBU81.983.05 dokumen UKL/ UPL tidak tersedia di kator 
SPBU, hal ini menunjukkan bahwa perhatian pihak manajemen SPBU terhadap pengelolaan dan pemeliharaan lingkungan hidup belum menjadi perhatian. Dengan demikian dapat disimpulkan bahwa secara umum ketiga SPBU di Manokwari dalam operasionalnya lebih mengutamakan kepentingan ekonomi dibanding kepentingan perlindungan lingkungan termasuk kesehatan dan keselamatan kerja serta kenyamanan pelanggan.

\section{KESIMPULAN DAN SARAN Kesimpulan}

1. Kepatuhan terhadap peraturan dan kebijakan lingkungan SPBU 84. 983.01dan SPBU 84.983.01 tergolong kriteria taat (baik), sedangkan SPBU 81.983.05 tergolong kriteria cukup taat (cukup baik).

2. Kelengkapan organisasi dan personil pada SPBU 84.983.01 dan SPBU 81.983.05 tergolong kriteria cukup taat (cukup baik) dan SPBU 84.983.02 tergolong kriteria taat (baik).

3. Kondisi fisik sarana lindungan lingkungan yang dimiliki oleh SPBU 84.983.01 tergolong kriteria cukup taat (cukup baik), SPBU 81.983.05 tergolong kriteria kurang baik dan SPBU 84.983.02 tergolong kriteria taat (baik).

4. Sistem pengelolaan lingkungan yang diimplementasikan oleh SPBU di Manokwari berdasarkan kepatuhan terhadap peraturan dan kebijakan, kelengkapan organisasi dan personil serta kondisi fisik sarana lingkungan yang dimiliki tampak bahwa SPBU 84.983.02 memiliki mutu pengelolaan pada kriteria baik dibanding dengan SPBU 84.983.01 dan 81.983.05 yang tergolong kriteria cukup baik.
5. Secara umum pihak manajemen dari ketiga SPBU di Manokwari dalam menjalankan usahanya masih lebih mengutamakan kepentingan ekonomi usahanya, sedangkan kepentingan perlindungan lingkungan hidup, kesehatan dan keselamatan kerja serta kenyamanan belum menjadi perhatian utama pihak manajemen SPBU.

\section{Saran}

1. Pihak manajemen SPBU perlu membuat kebijakan lingkungan sebagai komitmennya untuk melaksanakan semua peraturan perundangan lingkungan, pedoman LLK3 dan SOP yang disyaratkan, termasuk komitmen untuk melaksanakan program pengelolaan dan pemantauan lingkungan yang ditetapkan dalam dokumen UKL/ UPL.

2. Pihak manajemen SPBU perlu melengkapi sarana dan prasarana lindungan lingkungan termasuk sarana dan prasarana pendukung lain guna pengimplementasian pendukung LLK3 SPBU yang disyaratkan oleh PT. Pertamina (Persero).

3. PT.Pertamina (Persero) dan Intansi Pemerintah Daerah Cg. Bidang Lingkungan Hidup BP3D Manokwari perlu melakukan monitoring terhadap pengelolaan lingkungan di setiap SPBU di Manokwari terutama pelaksanaan UKL/UPL.

\section{DAFTAR PUSTAKA}

Courtier, L.1995. Kebijaksanaan Nasional dalam Pembangunan dan Lingkungan Hidup.

PT. Berkatnya Manokwari Abadi. 2010. Dokumen Upaya Pengelolaan Lingkungan dan Upaya Pemantauan Lingkungan Hidup (UKL 
dan UPL) SPBU 84.983.01.

Manokwari.

PT. Irian Agung Permai. 2010. Dokumen Upaya Pengelolaan Lingkungan dan Upaya Pemantauan Lingkungan Hidup (UKL dan UPL) SPBU 84.983.02, Manokwari.

Kuhre,W.Lee.1996. Sertifikasi ISO 14001: Sistem Pengelolaan Lingkungan. Prenhalindo. Jakarta.

PT. Pertamina. 2004a. Pedoman LLK3. PT.Pertamina (Persero). Jakarta.

PT. Pertamina. 2004b. Standar Operasional Prosedu (SOP). PT. Pertamina (Persero). Jakarta.

Sugiyono. 2014. Metode Penelitian Kombinasi (Mixed Methods). Alfabeta. Bandung.

Wiku, A. 2008. Audit Lingkungan Rumah Sakit. Edisi 1, Rajawali Pers. Jakarta. 